\title{
Self-Determination in Light of the International Court of Justice's Opinion in the Chagos Case
}

\author{
Gino J Naldi*
}

https://doi.org/10.21827/GroJIL.7.2.216-235

\begin{abstract}
KEYWORDS: CHAGOS ARCHIPELAGO; ICJ ADVISORY OPINION; SELFDETERMINATION; THE CRYSTALLISATION OF THE RIGHT TO SELFDETERMINATION; TERRITORIAL INTEGRITY; INTERNATIONAL RESPONSIBILITY
\end{abstract}

\begin{abstract}
In its Advisory Opinion in Legal Consequences of the Separation of the Chagos Archipelago from Mauritius in 1965, delivered in 2019, the International Court of Justice (ICJ) was of the view that the decolonisation of Mauritius by the United Kingdom had not been lawfully completed when it achieved independence in 1968. This was due to the separation of the Chagos Archipelago in 1965. After dismissing various challenges to the exercise of its advisory jurisdiction, including the argument that the issue at stake was a territorial dispute between the States and that its jurisdiction was, therefore, being misused to circumvent the United Kingdom's lack of consent to contentious proceedings, the ICJ felt it necessary to explore the nature, scope and content of the right to self-determination and whether it had been validly exercised in this instance. The ICJ found that self-determination had become established as a legal right in the context of decolonisation by the time Mauritius was in the process of securing its independence in the 1960s and that a corollary of the right was that of the territorial integrity of a non-self governing territory, which had not been respected in the case of Mauritius. Accordingly, the United Kingdom's continued administration of the Chagos Archipelago constituted an ongoing internationally wrongful act, entailing international responsibility, which the United Kingdom was under an obligation to put an end to as soon as possible. While it was for the United Nations (UN) General Assembly to determine how the decolonisation of Mauritius was to be realised, in view of the fact that the right to selfdetermination has an erga omnes character, the ICJ called on all States to co-operate with the $\mathrm{UN}$ to that end.
\end{abstract}

\section{Introduction}

In its Advisory Opinion in the Chagos case delivered in February 2019, the International Court of Justice (ICJ) expressed the view by an overwhelming majority that, inter alia, the decolonisation of Mauritius by the United Kingdom (UK), the colonial power, had not been lawfully completed when it achieved independence in 1968 as a result of the detachment of the Chagos Archipelago from Mauritius by the UK. Consequently, the UK's continued administration of the Chagos Archipelago constituted an ongoing international wrongful act 


\section{Self-Determination in Light of the International Court of Justice's Opinion in the \\ Chagos Case 217}

which the UK was under an obligation to bring promptly to an end. ${ }^{1}$ In the course of its judgement, the ICJ considered it necessary to explore the nature, scope and content of the right to self-determination and whether it had been validly exercised in this case. Of crucial significance was the determination as to when the right to self-determination had crystallised as a rule of customary international law. Its views on this and related issues relating to the territorial integrity of non-self-governing territories and the effect of duress on the validity of so-called devolution agreements between the colonial power and the non-self-governing territory will be considered contentious for those of a conservative disposition. The purpose of this paper is to reflect on these observations of the ICJ, particularly as regards selfdetermination.

\section{Background}

The status of certain islands in the Indian Ocean is disputed between Mauritius and the UK. The British Indian Ocean Territory (BIOT), a British Overseas Territory, is comprised of several island groups in the Chagos Archipelago dominated by Diego Garcia. The Chagos Archipelago had formed part of the British colony of Mauritius since 1814; however, in 1965, just a few years before Mauritius gained independence in 1968, the UK detached the Chagos Archipelago from Mauritius and Seychelles and established it as a separate overseas territory, the BIOT. ${ }^{2}$ This event followed from the Lancaster House Agreement of 1965. This was the devolution agreement negotiating the independence of Mauritius according to which, in return for accepting the separation of the Chagos Archipelago, the UK would, inter alia, pay Mauritius GBP 3 million in compensation and relinquish sovereignty thereover when it was no longer required for military use. However, the Lancaster House Agreement proved to be a festering sore, as Mauritius considered that its independence was made conditional on its ceding the Chagos Archipelago and that it had no option but to agree. The UK then proceeded to remove the inhabitants of the Archipelago, the Chagos Islanders or Chagossians, who were effectively prohibited from returning, in order to lease Diego Garcia to the USA as a military base. ${ }^{3}$ In 2016, it was announced that the US military base would continue until at least $2036 .{ }^{4}$ Mauritius was of the view that its right of self-determination was not respected, considering the BIOT a residual colonial legacy, and latterly began to assert its claim to sovereignty over

\footnotetext{
* LLM, PhD (Birmingham), former senior university lecturer in Law, United Kingdom; gnaldi@hotmail.com.

${ }^{1}$ Legal Consequences of the Separation of the Chagos Archipelago from Mauritius in 1965 (Chagos case) (Advisory Opinion) [2019] ICJ General List No 169; Judge Donoghue was the sole dissent on the substantive questions. For a summary of the case see Anna Meijknecht, 'Hague Case Law: Latest Developments' (2019) 66 Netherlands International Law Review 185.

${ }^{2}$ For more detailed factual information on the historical background, see Chagos case (n 1) [94-131]; Chagos Marine Protected Area Arbitration (Mauritius v United Kingdom) (Chagos Arbitration) (2015) 31 RIAA 359.

3 Jon Lunn, 'The Chagos Islanders' (House of Commons Library Briefing Paper No 4463, 2012) 18 <researchbriefings.files.parliament.uk/documents/SN04463/SN04463.pdf> accessed 1 December 2019; The Chagossians have been fighting unsuccessfully for a right to return for many years; in 2008, the House of Lords held that the British Government's prohibition on returning was lawful in $R$ (Bancoult) $v$ Secretary of State for Foreign \& Commonwealth Affairs (No.2) [2009] 1 AC 453; The European Court of Human Rights declared a case brought by the Chagossians inadmissible because their claims had been settled in the domestic courts Chagos Islanders $v$ United Kingdom App no 35622/04 (ECtHR, 20 December 2012).

${ }^{4}$ Jon Lunn, 'Disputes over the British Indian Ocean Territory: August 2018 Update' (House of Commons Library Briefing Paper No 6908, 2018) <researchbriefings.files.parliament.uk/documents/SN06908/SN06908.pdf> accessed 1 December 2019.
} 
the Chagos Archipelago. ${ }^{5}$ In 2010, Mauritius instituted arbitral proceedings contesting the legality of the British decision to create a Marine Protected Area (MPA) around the Chagos Archipelago under the United Nations Convention on the Law of the Sea. ${ }^{6}$ In 2015, the arbitral tribunal delivered its award in the Chagos Arbitration and, although a majority dismissed Mauritius' claims on the basis that it lacked jurisdiction insofar as aspects of the dispute concerned sovereignty over the Chagos Archipelago, it did find unanimously that the UK's repeated pledges as to the eventual return of the Chagos Archipelago to Mauritius were binding under international law. ${ }^{7}$ Failing progress between the two parties on the issue of sovereignty, and in light of the British reservation to the jurisdiction of the ICJ which excludes disputes with other Commonwealth States, ${ }^{8}$ Mauritius won over the UN General Assembly which, in June 2017, referred to the ICJ a request for an Advisory Opinion on the questions whether: (i) the process of the decolonisation of Mauritius had been lawfully completed when it achieved independence, following the separation of the Chagos Archipelago, having regard to international law and (ii) what were the consequences under international law of the continued administration of the Chagos Archipelago by the UK, including the inability of Mauritius to resettle the Chagossians on the Chagos Archipelago. ${ }^{9}$ The substance of the questions, therefore, related to the rights and obligations of States and were not about whether the Chagossians themselves had a right to self-determination, since that right was subsumed in the right to self-determination of Mauritius itself. ${ }^{10}$

\section{Competence of the ICJ and Exercise of Judicial Propriety}

The ICJ first had to dispose of several preliminary issues. The exercise of its advisory jurisdiction was challenged on a number of grounds, which will be considered briefly for the sake of completeness.

The ICJ first examined whether the questions put to it amounted to legal questions within the meaning of Article 96(1) of the Charter of the United Nations (UN Charter) and Article 65(1) of the Statute of the International Court of Justice (ICJ Statute). The ICJ had little difficulty in giving an affirmative and brisk answer, holding that the implications for international law regarding the process of the decolonisation of Mauritius and the continued

\footnotetext{
${ }^{5}$ See Chagos Arbitration (n 2) [103-104], [442-444]; Malcolm Shaw, Title to Territory in Africa (OUP 1986) 130134; TP Lynch, 'Diego Garcia: Competing Claims to a Strategic Isle' (1984) 16 Case Western Reserve Journal of International Law 101, 103.

${ }^{6}$ United Nations Convention on the Law of the Sea (adopted 10 December 1982, entered into force 16 November 1994) 1833 UNTS 3.

${ }^{7}$ Chagos Arbitration (n 2) [417-448]; See Stefan Talmon, 'The Chagos Marine Protected Area Arbitration: Expansion of the Jurisdiction of Part XV Courts and Tribunals' (2016) 65 International and Comparative Law Quarterly 927.

8 'Declarations recognizing as compulsory the jurisdiction of the International Court of Justice under Article 36, paragraph 2 of the Statute of the Court' (United Nations Treaty Collection, 15 October 1946) <treaties.un.org/pages/ViewDetails.aspx?src=IND\&mtdsg_no=I-4\&chapter=1\&clang=_en\#76> accessed 1 December 2019. In response to claims by Mauritius that it was prepared to leave the Commonwealth in order to circumvent this obstacle in 2004, the UK amended its acceptance of the ICJ's jurisdiction to exclude disputes with States which had been members of the Commonwealth; Legal Consequences of the Separation of the Chagos Archipelago from Mauritius in 1965 (Chagos case) (Written Statement of the United Kingdom) $2018<$ icjcij.org/files/case-related/169/169-20180215-WRI-01-00-EN.pdf> accessed 1 December 2019 para 5.19(b).

${ }^{9}$ United Nations General Assembly (UNGA) Resolution 71/292 (23 June 2017) UN Doc A Res 71/292.

${ }^{10}$ Jan Klabbers, 'Shrinking Self-Determination: The Chagos Opinion of the International Court of Justice' (2019) 8(2) ESIL Reflections.
} 


\section{Self-Determination in Light of the International Court of Justice's Opinion in the \\ Chagos Case 219}

UK administration of the Chagos Archipelago were legal questions within the scope of these provisions. ${ }^{11}$ This conclusion is consistent with the ICJ's prior jurisprudence in the Western Sahara case ${ }^{12}$ and other cases where it had rejected similar objections. ${ }^{13}$

The ICJ also dismissed the argument that the questions put to it did not meet the requirements of Article 65(2) of the ICJ Statute and that the true object of the request related to a bilateral dispute. The contention was that ICJ should, therefore, reformulate the questions put to it in order to reflect the real issues at stake or interpret them restrictively to exclude any effect on interested States. The ICJ observed that it was part of its judicial function to provide any necessary clarification should any questions be unclear..$^{14}$ It went on to state that there was no need to reformulate the questions put to it, although it had that capacity, because in posing these questions based on international law, the General Assembly was broadly envisaging the likely outcome of the law on the international community as a whole..$^{15}$ The ICJ's role was to state the law applicable to the facts presented to it and thus provide guidance to the General Assembly. ${ }^{16}$ It thus implicitly rejected the view that the request related to a territorial dispute. The ICJ has been consistent in its approach that it does not take a restrictive interpretation of the provisions in question. ${ }^{17}$ Nevertheless, it is hard to escape the sense that if the ICJ had given a negative answer to the first question, it would prove damaging to the UK's continued title. $^{18}$

Having found unanimously that it possessed jurisdiction, the ICJ addressed the question of whether it should nevertheless exercise its discretionary powers to decline jurisdiction in order to preserve the integrity of its judicial function. Here, there was disagreement on the Bench. Consistent with its previous jurisprudence, the ICJ stated that it should not 'in principle' refuse to answer a question because it thereby participates in the work of the UN unless 'compelling reasons' exist. ${ }^{19}$ Were such 'compelling reasons' present in this case?

The first argument the ICJ addressed was that advisory proceedings were unsuited to determining disputed and complex facts. The ICJ observed that the critical issue was whether it was in possession of sufficient information in order to enable it to perform its judicial

\footnotetext{
${ }^{11}$ Chagos case (n 1) [57-59].

${ }^{12}$ Western Sahara (Advisory Opinion) [1975] ICJ Rep 12, 17-19; see Frank Wooldridge, 'The Advisory Opinion of the International Court of Justice in the Western Sahara Case' (1979) 8 Anglo-American Law Review 86, 98103.

${ }^{13}$ Legality of the Threat or Use by a State of Nuclear Weapons (Legality of Nuclear Weapons case) (Advisory Opinion) [1996] ICJ Rep 226 [10-13]; Legal Consequences of the Construction of a Wall in the Occupied Palestinian Territory (Wall case) (Advisory Opinion) [2004] ICJ Rep 136 [36].

${ }^{14}$ Chagos case (n 1) [60-61]; see also Wall case (n 13) [38].

${ }^{15}$ Chagos case (n 1) [135-136]; see also Wall case (n 13) [38]; Judge Donoghue would have limited the ICJ's reply to the first question only in order to avoid any impropriety, see Chagos case (n 1) Diss Op Judge Donoghue [22].

${ }^{16}$ Chagos case (n 1) [132-137]; Wall case (n 13) [38].

${ }^{17}$ See for example Western Sahara case (n 12) [39-47].

${ }^{18}$ See Chagos case (n 1) Diss Op Judge Donoghue [16-19].

${ }^{19}$ Chagos case (n 1) [65]; see Interpretation of Peace Treaties (Advisory Opinion) [1950] ICJ Rep 65, 72; Legality of Nuclear Weapons case (n 13) [14]; Wall case (n 13) [44].
} 
function, which it concluded that it was. ${ }^{20}$ It had been supplied with significant amounts of data and many States had submitted presentations to it. It cited with approval its dictum in the Namibia case, ${ }^{21}$ that a court must be 'acquainted with, take into account and, if necessary, make findings as to the relevant factual issues. ${ }^{22}$ The ICJ has much experience of weighing up questions of fact and, as long as it has the necessary documentation, to suggest that such issues are beyond its comprehension seems like lèse-majesté. ${ }^{23}$

The next consideration was the argument that the ICJ's Opinion would not assist the General Assembly in its work. The ICJ stated that it was for the General Assembly, rather than the ICJ itself, to determine the usefulness of the Opinion. ${ }^{24}$ The ICJ was, again, able to rely on previous pronouncements to this effect. ${ }^{25}$

The ICJ then had to consider the submission that the Advisory Opinion would reopen the decision in the Chagos Arbitration and would thus be contrary to the principle of res judicata. In dismissing this argument, the ICJ first indicated that its Opinion is given to the organ requesting it, not States. ${ }^{26}$ It then stated that the principle of res judicata does not prevent the ICJ from giving an Advisory Opinion. ${ }^{27}$ It finally made the obvious point that the issues decided in the Chagos Arbitration were different from those before the ICJ. ${ }^{28}$

The final objection the ICJ had to consider was that the Advisory Opinion would necessarily deal with issues of territorial sovereignty in dispute between the UK and Mauritius and would, therefore, circumvent the principle that no State can, without its consent, be compelled to submit a dispute to judicial settlement. ${ }^{29}$ The ICJ's position was that the General

${ }^{20}$ Chagos case (n 1) [71] [73]; the ICJ found that it had sufficient documentation and information in the Western Sahara case (n 12) [46-47]; and the Wall case (n 13) [55-58].

${ }^{21}$ Legal Consequences for States of the Continued Presence of South Africa in Namibia (South West Africa) notwithstanding Security Council Res. 276 (1970) (Namibia case) (Advisory Opinion) [1971] ICJ Rep 16, 74.

${ }^{22}$ Chagos case (n 1) [72].

${ }^{23}$ Hersch Lauterpacht, The Function of Law in the International Community (Clarendon Press 1933) 157; however, the lack of adequate materials led to the Permanent Court of International Justice declining jurisdiction in Case Concerning the Status of Eastern Carelia (Advisory Opinion) 1923 PCIJ Rep Series B No 5, 28.

${ }^{24}$ Chagos case (n 1) [76-77].

${ }^{25}$ See for example Legality of Nuclear Weapons case (n 13); Accordance with International Law of the Unilateral Declaration of Independence in Respect of Kosovo (Kosovo case) (Advisory Opinion) [2010] ICJ Rep 403, 417.

${ }^{26}$ See Interpretation of Peace Treaties case (n 19) 71.

${ }^{27}$ Difference relating to Immunity from Legal Process of a Special Rapporteur of the Commission on Human Rights Advisory Opinion [1999] ICJ Rep 62 [25]; Interpretation of Peace Treaties case (n 19) Sep Op Judge Azevedo [79-80]; Res judicata applies to judgments, per Manley O Hudson, The Permanent Court of International Justice 1920-1942 (MacMillan 1943) 592; Namibia case (n 21) Sep Op Judge de Castro [4].

${ }^{28}$ Chagos case (n 1) [81]; see Interpretation of Peace Treaties case (n 19) [72]; Johannes Hendrick Fahner, 'Déjà Vu in The Hague - The Relevance of the Chagos Arbitral Award to the Proceedings before the ICJ' (2018) 55 Questions of International Law 107.

${ }^{29}$ See for example Written Statement of the United Kingdom (n 8) para 7.5-7.9; Legal Consequences of the Separation of the Chagos Archipelago from Mauritius in 1965 (Chagos case) (Written Statement of the French Republic) <icj-cij.org/files/case-related/169/169-20180227-WRI-03-00-EN.pdf> accessed 1 December 2019; Legal Consequences of the Separation of the Chagos Archipelago from Mauritius in 1965 (Chagos case) (Written Statement of the United States of America) 2018 <icj-cij.org/files/case-related/169/169-20180301-WRI-01-00-EN.pdf> accessed 1 December 2019 Ch III; see also S Yee, 'Notes on the International Court of Justice (Part 7) - The Upcoming Separation of the Chagos Archipelago Advisory Opinion: Between the Court's Participation in the UN's Work on Decolonization and the Consent Principle in International Dispute Settlement' (2018) 16 Chinese Journal of International Law 623, 641; it is a fundamental principle that no State can, without its consent, be compelled to 


\section{Self-Determination in Light of the International Court of Justice's Opinion in the Chagos Case 221}

Assembly's request was not an attempt to circumvent a State's opposition and bring an existing dispute between States to court, but related to the decolonisation of Mauritius. The General Assembly has a long record in seeking to bring about an end to colonialism and the Opinion would assist it in its decolonisation policy. ${ }^{30}$ Essentially, the ICJ stressed the General Assembly's reliance on the ICJ in exercising its functions relating to decolonisation. The fact that the ICJ may have to pronounce on legal questions on which Mauritius and the UK had different views did not mean that it would be deciding a bilateral dispute..$^{31}$ The ICJ followed closely its approach in the Western Sahara case, where it had rejected Spain's objections to the exercise of advisory jurisdiction based on its lack of consent to the adjudication of what it claimed was in essence a bilateral dispute, ${ }^{32}$ and the Wall case, which engaged the UN's powers and responsibilities concerning international peace and security. ${ }^{33}$ However, Judge Tomka expressed his scepticism on this matter, pointing out that the issue of the Chagos Archipelago had not been on the UN's agenda for decades and that in the background lurked a dispute between the two States. ${ }^{34}$ However, this underestimates the central and sustained role played by the General Assembly in facilitating decolonisation and its continued interest in the issue, as the ICJ observed..$^{35}$ Judge Donoghue was similarly of the view that the ICJ's advisory jurisdiction was being used to bypass a bilateral dispute and that that amounted to a sufficient reason to decline the request for an opinion. ${ }^{36}$ In the present case, decolonisation and sovereignty could not be separated, whereas the Western Sahara case could be distinguished because there the ICJ had found that at stake were Morocco's rights at the time of colonisation in the 1880s and Spain's rights as administering power in the 1970s remained unaffected. ${ }^{37}$ However, for Vice-President Xue, while accepting that Mauritius and the UK were in dispute over the Chagos Islands, this was not the material issue. The ICJ had frequently faced protestations that it was overriding a lack of consent from States for the adjudication of disputes, when the crux of the matter was the object and nature of the request. ${ }^{38}$ The present request was to provide assistance to the General Assembly on the decolonisation of Mauritius, not on resolving a bilateral dispute. ${ }^{39}$ The view has been expressed that the wording of the questions in Resolution 71/292 shrewdly minimised the possibility of a challenge on this ground succeeding. ${ }^{40}$

These preliminary issues have been raised before the ICJ on numerous occasions, albeit without much success. Unlike in those cases, the ICJ did not dwell at length on the intricacies

submit its disputes to any kind of pacific settlement, see for example Case Concerning the Status of Eastern Carelia (n 23) [7]; Western Sahara case (n 12) [32-33]; Wall case (n 13) [47]; Kosovo case (n 25) [29].

${ }^{30}$ Chagos case (n 1) [86-90]; see also Wall case (n 13) [49].

${ }^{31}$ Chagos case (n 1) [89]; Judge Tomka was unable to agree with the ICJ on this point, Chagos case (n 1) Declaration Judge Tomka [6-7]; see also Namibia case (n 21) [34]; Wall case (n 13) [48].

${ }^{32}$ Western Sahara case (n 12) [39-43].

${ }^{33}$ Wall case (n 13) [48 -49]; see also Namibia case (n 21) [32].

${ }^{34}$ Chagos case (n 1) Declaration Judge Tomka [5-7].

${ }^{35}$ Chagos case (n 1) [87].

${ }^{36}$ Chagos case (n 1) Diss Op Judge Donoghue [3].

${ }^{37}$ Chagos case (n 1) Diss Op Judge Donoghue [16-17].

${ }^{38}$ Chagos case (n 1) Declaration Vice-President Xue [4].

${ }^{39}$ Chagos case (n 1) Declaration Vice-President Xue [2-5].

${ }^{40}$ Marko Milanovic, 'ICJ Advisory Opinion Request on the Chagos Islands' (EJIL:TALK!, 24 June 2017) <ejiltalk.org/icj-advisory-opinion-request-on-the-chagos-islands/> accessed 1 December 2019. 
of these arguments but drew on a significant body of precedent to dispose of them succinctly. Its conclusions continue in the same vein as its previous jurisprudence and hence give little cause for surprise, although fears were expressed that, given the background of the affair, the question of lack of consent might pose a significant difficulty. ${ }^{41}$ It seems evident that the ICJ will err on the side of jurisdiction when an issue is of 'particular concern' to the UN. ${ }^{42}$ However, given the implications for existing claims to sovereignty, the ICJ's somewhat blasé approach may give cause for disquiet.

\section{The Applicable Law of Self-Determination}

In order to answer the first question put to it (whether the decolonisation of Mauritius been lawfully completed when it gained independence), the ICJ considered it necessary to initially determine the law on self-determination applicable at the relevant time, which was deemed to be the period between the detachment of the Chagos Archipelago in 1965 and the independence of Mauritius in 1968. This was the fundamental issue on which the whole course of the case depended. If self-determination had become established as a rule of customary international law by 1965, it would almost certainly follow that the UK would have been under an obligation to respect the territorial integrity of Mauritius and the separation of the Chagos Archipelago would be deemed illegal. If it had not, the UK could not be found to have acted contrary to international law. The ICJ applied the doctrine of intertemporal law, not as a snapshot in time but to take account of the evolution of the law, including later instruments reinforcing or interpreting existing rules. ${ }^{43}$ In the circumstances of the case before it, the ICJ considered self-determination in the context of decolonisation, ${ }^{44}$ that is, in its external manifestation. ${ }^{45}$ It should be noted that the ICJ took it for granted, as it had done in the Frontier Dispute case, that self-determination was a binding norm of current international law in this field. ${ }^{46}$ Indeed, all parties were in agreement on this point. Many judges regretted that the ICJ had failed to take the opportunity to emphasise that self-determination had become established as a jus cogens norm in contemporary international law, ${ }^{47}$ although it did

\footnotetext{
${ }^{41}$ Julia Wagner, 'The Chagos Request and the Role of the Consent Principle in the ICJ's Advisory Jurisdiction, or: What to do When Opportunity Knocks' (2018) 55 Questions of International Law 177.

${ }^{42}$ Chagos case (n 1) [88]; See also Wall case (n 13) [49]; see further Wagner (n 41) 183.

${ }^{43}$ Chagos case (n 1) [140-143]; the ICJ had previously taken this approach in the Namibia case (n 21) [53]; the modern doctrine of intertemporal law was set out in the Island of Palmas case [1928] 2 RIAA 829 [845]; see RL Bledsoe and BA Boczek, International Law Dictionary (ABC-Clio 1987) 15.

${ }^{44}$ Chagos case (n 1) [144]; the UK had argued that decolonisation was a political process and not a legal right or principle, Written Statement of the United Kingdom (n 8) para 8.9.

${ }^{45}$ See Reference re Secession of Quebec [1998] 2 SCR 217, 282.

${ }^{46}$ Frontier Dispute (Mali/Burkina Faso) [1986] ICJ Rep 568 (Frontier Dispute case); this is now universally accepted and the jurisprudence of the ICJ leaves no room for doubt, see Namibia case (n 21) [52]; Western Sahara case (n 12) [55]; East Timor (Portugal v Australia) [1995] ICJ Rep 90 [29]; Wall case (n 13) [87-88], [155-156]; see also, Delimitation of Maritime Boundary between Guinea-Bissau and Senegal (1989) 20 RIAA119 [135]; Case C-104/16 P Council v Front Polisario [2016] EU:C:2016:973 [88]; Secession of Quebec case (n 30) [278]; see further: Antonio Cassese, Self-Determination of Peoples: A Legal Reappraisal (CUP 1995) 109, 115; Rosalyn Higgins, Problems and Process: International Law and How We Use It (OUP 1994) 114-128; Robert Y Jennings and Sir Arthur Watts (eds) Oppenheim's International Law, Vol 1 (9 ${ }^{\text {th }}$ ed, Longman 1992) 285; Ian Brownlie, Principles of Public International Law (7th ed, OUP 1990) 580-582; James R Crawford, The Creation of States in International Law (2 ${ }^{\text {nd }}$ ed, OUP 2007) 112-114.

${ }^{47}$ Chagos case (n 1) Sep Op Judge Cançado-Trindade [118-150]; Sep Op Judge Sebutinde [25]; Sep Op Judge Robinson [48-56].
} 


\section{Self-Determination in Light of the International Court of Justice's Opinion in the}

Chagos Case 223

describe it as 'a fundamental human right'. ${ }^{48}$ This was an important consideration due to the possible consequences flowing from a finding of a breach thereof.

Secondly, the ICJ ascertained the content of the law. Considering the difference in opinion expressed by interested States, including the submission that self-determination did not form an accepted part of international law at that time,${ }^{49}$ the ICJ proceeded to explain how the law on self-determination had emerged and developed.

The starting point was the UN Charter, specifically Article 1(2) and Chapter XI thereof, which made the principle of self-determination one of the UN's purposes. ${ }^{50}$ Whether it amounted to a legal right in 1945 , as opposed to a political concept, is doubtful, ${ }^{51}$ but the decolonisation policy that was pursued in the 1950s and 1960s by the UN itself as well as States led to a change in its status. However, the answer to the question that the ICJ wished to determine was exactly when self-determination had crystallised into a rule of customary law. This was an important undertaking, given that criticism of its previous jurisprudence on the subject has been regarding lacunae in the ICJ 's reasoning on this issue. ${ }^{52}$

The notable event for the ICJ was the adoption of the celebrated General Assembly Resolution 1514 (XV) 1960, the Declaration on the Granting of Independence to Colonial Countries and Peoples, which had an immediate impact on, and gave impetus to, the decolonisation process. ${ }^{53}$ The ICJ proceeded to attribute to Resolution 1514 (XV) a 'declaratory character with regard to the right to self-determination as a customary norm, in view of its content and the conditions of its adoption. ${ }^{54}$ The ICJ considered the wording of the Resolution to have a normative character and observed that it had been adopted by a large

\footnotetext{
${ }^{48}$ Chagos case (n 1) 144.

${ }^{49}$ Written Statement of the United Kingdom (n 8) para 8.64-8.77; Written Statement of the United States of America (n 29) para 4.30-4.72; see generally James Summers, 'Decolonisation Revisited and the Obligation not to Divide a Non-Self-Governing Territory' (2018) 55 Questions of International Law 147, 151-161.

${ }^{50}$ Chagos case (n 1) [146-148]; see also Namibia case (n 21) [52]; Western Sahara case (n 12) [54]; East Timor case (n 46) Sep Op Judge Weeramantry [139], [194-195]; see further, Thomas D Musgrave, Self-Determination and National Minorities (OUP 2000) 62-66; it needs to be recalled that when called upon to interpret the UN Charter as a constitutional text, the ICJ has adopted a teleological approach of treaty interpretation which allows the aims and purposes of the organisation to be achieved in the contemporary context even if they are not provided for expressly, Reparation for Injuries case [1949] ICJ Rep 174; Certain Expenses of the United Nations case [1962] ICJ Rep 151; indeed, the ICJ relied on the teleological rule of treaty interpretation in the Namibia case (n 21) [47-53] to support its view that the principle of self-determination was derived from the UN Charter.

${ }^{51}$ Cassese (n 46) 37-43; Crawford (n 46) 108-112; Higgins (n 46) 111-112; Wooldridge (n 12) 104; JP Grant and JC Barker, Parry \& Grant Encyclopaedic Dictionary of International Law (3rd ed, OUP 2009) 550; Peter Malanczuk, Akehurst's Modern Introduction to International Law (7th ed, Routledge 1997) 326; Malcolm Shaw International Law (6th ed, CUP 1997) 252; Daniel Thürer and Thomas Burri, 'Self-Determination' in Max Planck Encyclopedia of Public International Law <opil.ouplaw.com/view/10.1093/law:epil/9780199231690/law-9780199231690e873?rskey=GK5vMM\&result=3\&prd=OPIL $>$ accessed 1 December 2019.

${ }^{52}$ Wooldridge (n 12) 105; see also Namibia case (n 21) Sep Op Judge Ammoun, 74.

${ }^{53}$ Chagos case (n 1) [150]; see also Namibia case (n 21) [52]; Western Sahara case (n 12) [56]; Cassese (n 46) 70; Shaw (n 50) 252-253.

${ }^{54}$ Chagos case (n 1) [152]; the main judgement's conclusion was supported by a number of judges; see Chagos case (n 1) separate opinion of judge Cançado-Trindade; Chagos case (n 1) separate opinion of judge Robinson; Chagos case (n 1) separate opinion of judge Sebutinde.
} 
majority with no State questioning the existence of this right. ${ }^{55}$ The ICJ was thus satisfied that the constituent elements of custom, opinio juris and State practice, were met in this instance. ${ }^{56}$ 1960 would thus appear to be the latest possible date at which self-determination had hardened into a right. According to some individual judges, self-determination had already achieved the status of jus cogens. ${ }^{57}$ The African Union also took this position, ${ }^{58}$ as did South Africa. ${ }^{59}$

The ICJ's conclusion is bound to be highly controversial on several grounds. Without delving into the debate on the normative effect of General Assembly Resolutions and accepting for present purposes, as the ICJ observed, that General Assembly Resolutions may provide evidence of opinio juris, ${ }^{60}$ the crucial question is whether this is true of Resolution 1514 (XV) as regards the critical period between 1965 and 1968. The interpretation of the developments in question by the UK and US were diametrically opposed to that of the ICJ. Both States considered that Resolution 1514 (XV) neither reflected nor generated customary law in 1960, nor in its immediate aftermath, taking the position that it was not couched in legal terminology and that the requisite opinio juris was lacking as a result of the differing attitudes of States. ${ }^{61}$ By way of contrast, the African Union in its Written Statement argued that the sources of international law, beginning with a series of General Assembly Resolutions adopted in the 1950s, in association with widespread State practice, confirmed that a right to self-determination existed in customary law by the time Resolution 1514 (XV) was adopted. ${ }^{2}$

\footnotetext{
${ }^{55}$ Chagos case (n 1) [152-153]; accordingly, one jurist writes that 'the resolution represents a consensus as to what the concept of self-determination means under the UN Charter', Vaughan Lowe, International Law (OUP 2007) 91.

${ }^{56}$ The ICJ stated that the adoption of UNGA Res 2625 (24 October 1970) UN Doc A/Res/2625, Declaration on Principles of International Law, merely confirmed the normative character of self-determination under customary law, Chagos case (n 1) [155]; Judge Salam would also have invoked relevant Security Council Resolutions, Chagos case (n 1) Declaration Judge Salam [3].

${ }^{57}$ Chagos case (n 1) Sep Op Judge Cançado-Trindade [122-128]; Chagos case (n 1) Sep Op Judge Robinson [7173]; Chagos case (n 1) Sep Op Judge Sebutinde [13].

${ }^{58}$ Legal Consequences of the Separation of the Chagos Archipelago from Mauritius in 1965 (Chagos case) (Written Statement of the African Union) 2018 <icj-cij.org/files/case-related/169/169-20180301-WRI-07-00-EN.pdf> accessed 1 December 2019 Part III, II.G.

${ }^{59}$ Legal Consequences of the Separation of the Chagos Archipelago from Mauritius in 1965 (Chagos case) (Written Statement of the Republic of South Africa) <icj-cij.org/files/case-related/169/169-20180301-WRI-12-00EN.pdf $>$ accessed 1 December 2019 para 63; it is interesting to note that in 1975, both Spain and Algeria had argued before the ICJ in the Western Sahara case that self-determination acquired the status of a norm jus cogens, Western Sahara ICJ Pleadings Vol I 206-208, Vol IV 497-500, Vol V 318-20.

${ }^{60}$ Chagos case (n 1) [151]; see Military and Paramilitary Activities in and Against Nicaragua (Nicaragua v United States of America) (Nicaragua case) [1986] ICJ Rep 14 [99-100]; Legality of Nuclear Weapons case (n 13) [70].

${ }^{61}$ Written Statement of the United Kingdom (n 8) para 8.32-8.48; Written Statement of the United States of America (n 29) para 4.27-4.29, 4.42-4.72; see Brownlie (n 46) 580, who writes that the 'generality and political aspect of the principle do not deprive it of its legal content'.

${ }^{62}$ Written Statement of the African Union (n 58) paras 77-93, 96-97.
} 


\section{Self-Determination in Light of the International Court of Justice's Opinion in the Chagos Case 225}

This stance was shared by Cyprus, ${ }^{63}$ the Netherlands, ${ }^{64}$ Serbia $^{65}$ and South Africa, ${ }^{66}$ among others. Since evidence of opinio juris requires meticulous evaluation, the ICJ's approach seems somewhat cursory, particularly when compared to the thorough study made by the US and other participants. This is glaringly evident when contrasted with the ICJ's consideration of the subject in cases such as the North Sea Continental Shelf ${ }^{67}$ or the Nicaragua case, ${ }^{68}$ among others. Although the ICJ invoked the UN Charter, Resolution 1514(XV) and developments in international society over a number of years, including the decolonisation policy of States, ${ }^{69}$ it did not consider it necessary to recapitulate in full the authorities supportive of the emergence of the right. The ICJ could have presented a more considered and persuasive case on this issue, as judges in their individual opinions did, ${ }^{70}$ to rebut convincingly the UK and US' arguments.

Certainly, insofar as the ICJ's case-law is concerned, by the time of its Advisory Opinion in the Namibia case in 1971, the ICJ was of the view that self-determination had hardened into a legal right, acknowledging the significance of Resolution $1514(\mathrm{XV}),{ }^{71}$ although it failed to provide a detailed and reasoned justification as to how this had come about. ${ }^{72}$ The ICJ had previously iterated this contention in 1975 in the Western Sahara case, stating that the 'principle of self-determination as a right of peoples, and its application for the purpose of bringing all colonial situations to a speedy end, were enunciated' in Resolution $1514(\mathrm{XV})$, describing it as the 'basis for the process of decolonization which has resulted since 1960 in the creation of many States'.$^{73}$ Judge Dillard expressed the view that 'a norm of international law has emerged applicable to ... decolonisation' ${ }^{74}$ In the East Timor case, Judge Weeramantry drew attention to the pivotal role self-determination had been allocated in the

\footnotetext{
${ }^{63}$ Legal Consequences of the Separation of the Chagos Archipelago from Mauritius in 1965 (Chagos case) (Written Statement Commenting on other Written Statements submitted by Cyprus) $2018<$ icj-cij.org/files/case-related/169/16920180511-WRI-01-00-EN.pdf $>$ accessed 1 December 2019 paras 17-18.

${ }^{64}$ Legal Consequences of the Separation of the Chagos Archipelago from Mauritius in 1965 (Chagos case) (Written Statement of the Netherlands) <www.icj-cij.org/files/case-related/169/169-20180227-WRI-01-00-EN.pdf> accessed 1 December 2019 paras 3.4-3.8.

${ }^{65}$ Legal Consequences of the Separation of the Chagos Archipelago from Mauritius in 1965 (Chagos case) (Written Observations by Serbia) $2018<$ icj-cij.org/files/case-related/169/169-20180515-WRI-06-00-EN.pdf> accessed 1 December 2019 paras 30, 33.

${ }^{66}$ Written Statement of the Republic of South Africa (n 58) para 63.

${ }^{67}$ North Sea Continental Shelf [1969] ICJ Rep 3 [70-81].

${ }^{68}$ Nicaragua case (n 60) [176-178], [183-207].

${ }^{69}$ On the United Kingdom's practice in decolonisation see Robert McCorquodale, 'Negotiating Sovereignty: The Practice of the United Kingdom in Regard to the Right of Self-determination' (1995) 66 British Yearbook of International Law 283. France granted independence to the overwhelming majority of its colonial possessions by 1960, Crawford (n 46) Appendix 1.

${ }^{70}$ See $\mathrm{n} 57$.

${ }^{71}$ Namibia case (n 21) [52]; Judge Ammoun relied on the widespread practice of States in decolonisation, further endorsed by the UN Charter and numerous UN declarations and resolutions, Namibia case (n 21) Sep Op Judge Ammoun, 55, 73-75.

${ }^{72}$ Wooldridge (n 12) 105-106.

${ }^{73}$ Western Sahara case (n 12) [55], 57].

${ }^{74}$ Western Sahara case (n 12) Sep Op Judge Dillard, 121-122.
} 
structure of the UN Charter, establishing it as one of its fundamental principles. He described Resolution $1514(\mathrm{XV})$ as a landmark declaration. ${ }^{75}$ In the Kosovo case, the ICJ referred to the 'second half of the twentieth century' as the crucial period, ${ }^{76}$ whereas in the Chagos Arbitration Judge Kateka and Judge Wolfrum were of the view that self-determination had become established as a principle before $1970 .{ }^{77}$ However, no indication as to precise dates was given in these cases, although the ICJ's statements in the Western Sahara case are capable of being interpreted as identifying 1960 as the decisive date. This is only to be expected, as there is an inherent element of uncertainty as to the length of time involved in the formation of a customary law. ${ }^{78}$

There is also some academic support for the notion that the principle of selfdetermination had emerged sooner rather than later. ${ }^{79}$ Judge Cançado-Trindade's interpretation of the evidence in his Separate Opinion is illuminating, reflecting in part the approach of the African Union. He relied similarly on a number of General Assembly Resolutions prior to and post-1960, supported by the work of international organisations such as the Organisation of African Unity, and the stance of blocs such as the Latin American States, to recount the evolution of the right to self-determination at this time. ${ }^{80}$ Judge Robinson emphasised the importance of Resolution $1514(\mathrm{XV})$, which he described as a 'watershed' ${ }^{81}$ Resolution 1514(XV) was the culmination of a series of Resolutions adopted in the 1950s which, unlike the earlier Resolutions, clarified the details of the right to self-determination. ${ }^{82}$ He was of the opinion that self-determination had crystallised into a rule of customary law by 1960 at the latest. ${ }^{83}$

However, others suggest that the right to self-determination may not have become established earlier than 1970, with the adoption of UN General Assembly Resolution $2625(\mathrm{XXV}){ }^{84}$ This was the position of the $\mathrm{UK}^{85}$ and the USA. ${ }^{86}$

Although the ICJ did not provide a fully articulated argument to support its finding that self-determination had crystallised into a norm of customary law by the 1960s, a considerable body of evidence was submitted by participants and addressed by individual judges to make that conclusion plausible.

The ICJ turned its attention to the relationship between the rights of self-determination and territorial integrity, which form essential components of the norms on decolonisation of non-self-governing territories. It observed that the latter aspect of self-determination finds

\footnotetext{
${ }^{75}$ East Timor case (n 46) Sep Op Judge Weeramantry, 196.

${ }^{76}$ Kosovo case (n 25) [79].

${ }^{77}$ Chagos Arbitration (n 2) Dissenting and Concurring Opinion Judge Kateka and Judge Wolfrum 585, 601.

78 Antonio Cassese, International Law (2 ${ }^{\text {nd }}$ ed, OUP 2005) 157-158.

79 Brownlie (n 46) 580-581; Cassese (n 46) 69-72; Crawford (n 46) 604; Shaw (n 50) 253; M Lachs, 'The law in and of the United Nations' (1960-61) 1 Indian Journal of International Law 429.

${ }^{80}$ Chagos case (n 1) Sep Op Judge Cançado-Trindade [45-55].

${ }^{81}$ Chagos case (n 1) Sep Op Judge Robinson [39].

${ }^{82}$ Chagos case (n 1) Sep Op Judge Robinson [40-41].

${ }^{83}$ Chagos case (n 1) Sep Op Judge Robinson [42].

${ }^{84}$ Higgins (n 46) 113; Malanczuk (n 51) 327, 331; in the Western Sahara case, Judge Petrén appeared to suggest that the law on self-determination was de lege ferenda, Western Sahara case (n 12) 110.

${ }^{85}$ Written Statement of the United Kingdom (n 8) para 8.75.

${ }^{86}$ Written Statement of the United States of America (n 29) para 4.61.
} 


\section{Self-Determination in Light of the International Court of Justice's Opinion in the}

Chagos Case 227

expression in paragraph six of Resolution $1514(\mathrm{XV}){ }^{87}$ which seeks to prevent the dismemberment of a non-self-governing territory ${ }^{88}$ With regard to Mauritius, the General Assembly had, in its Resolution 2066(XX) 1965 specifically requested the UK to not take any action which might dismember the territory of Mauritius. ${ }^{89}$ Moreover, the ICJ found that the Chagos Archipelago had formed part of Mauritius at the time of detachment by the UK. ${ }^{90}$ Contrary to the arguments advanced by the UK in particular, ${ }^{91}$ the ICJ drew attention to the fact that self-determination as a right of peoples pertains to the entirety of the territory. Moreover, the right to territorial integrity was recognised in pre-existing customary law as a 'corollary' of self-determination. ${ }^{92}$ This conclusion of the ICJ appears correct. ${ }^{93}$ If there had heretofore been uncertainty as to its status as a customary rule, the ICJ's pronouncement has removed that doubt. ${ }^{94}$ However, there were indications that this right may not be absolute, as the ICJ went on to state that any detachment 'unless based on the freely expressed and genuine will of the people of the territory concerned' would be contrary to the right of selfdetermination. ${ }^{95}$ This would appear to allow for a partition to be permissible under international law if legitimately approved by a majority of the entirety of the non-selfgoverning territory in question. ${ }^{96}$

The application of the right of self-determination necessitated that the inhabitants of non-self-governing territories freely determine their political status. The ICJ noted that Resolution 1541(XV) contemplates the possibilities of independence, free association and integration but the choice must be the result of the free and genuine expression of the will of

\footnotetext{
87 'Any attempt at the partial or total disruption of the national unity and the territorial integrity of a country is incompatible with the purposes and principles of the [UN] Charter'; See further UNGA Res 2625 (1970) (n 56). ${ }^{88}$ Chagos case (n 1) [153].

${ }^{89}$ Chagos case (n 1) [165]; the ICJ observed that the General Assembly had on many occasions called for the territorial integrity of non-self-governing territories to be respected, Chagos case (n 1) [68].

${ }^{90}$ Chagos case (n 1) [170].

${ }^{91}$ Written Statement of the United Kingdom (n 8) paras 8.27-8.31.

${ }^{92}$ Chagos case (n 1) [160]; Judge Sebutinde went further and described it as a non-derogable rule, Chagos case (n 1) Sep Op Judge Sebutinde [40].

${ }_{93}$ Chagos Case (n 1) Sep Op Judge Robinson [33]; Cassese (n 46) 72-73; see also Chagos Arbitration (n 2) Dissenting and Concurring Opinion Judge Kateka and Judge Wolfrum 585, 601. Mauritius had pointed out that upon the independence of the Seychelles in 1976, the UK had returned to the Seychelles various islands which the UK had separated from the Seychelles in 1965, Legal Consequences of the Separation of the Chagos Archipelago from Mauritius in 1965 (Chagos case) (Written Statement of the Republic of Mauritius) 2018 <icj-cij.org/files/caserelated/169/169-20180301-WRI-05-00-EN.pdf $>$ accessed 1 December 2019 paras 3.95, 3.110; a successful example of incorporation assisted by the UN is that of Walvis Bay into Namibia, see Musgrave (n 50) 253; Gino J Naldi, Constitutional Rights in Namibia (Juta 1995) 26-27.

${ }^{94}$ It has been observed that the UN's position has hardly been consistent, Summers (n 49) 161-167; Crawford gives a guarded assessment: 'It is an established part of United Nations' practice and may be treated as a presumption as to the operation of self-determination in particular cases; thus, the division of a self-determination unit into fragments for purpose of avoiding the principle of self-determination would be unlawful' Crawford ( $\mathrm{n}$ 46) 336.

${ }^{95}$ Chagos case (n 1) [160], [172]; see also Chagos case (n 1) Declaration of Judge Iwasawa.

${ }^{96}$ See also Chagos case (n 1) Declaration Judge Abraham; Chagos case (n 1) Sep Op Judge Gaja [1]; Summers (n 49) 172-173; an example of a sanctioned separation is that of Gilbert and Ellice Islands as the independent States of Kiribati and Tuvalu, Crawford (n 46) 336 at note 26; by way of contrast, the separation of Mayotte from Comoros to remain under French administration is rejected by the UN notwithstanding that it is supported by the local population, Crawford (n 46) 645-646; Musgrave (n 50) 184-185.
} 
the people. ${ }^{97}$ The General Assembly had a measure of discretion with respect to the form and procedure by which self-determination is to be realised and, while international law does not impose any particular method by which the inhabitants of non-self-governing territories must exercise their right to self-determination, whichever mode employed must reflect the freely expressed will of the people. ${ }^{98}$ This was the outcome of the process. The indispensable feature remains the basic need to consider the wishes of the people concerned through informed and democratic processes. Clearly, no such consultation had taken place as Mauritius advanced towards independence. The ICJ closely followed its previous pronouncements in the Western Sahara case, where it set the fundamental requirements for the exercise of the right to selfdetermination in some detail. ${ }^{99}$

In light of the fact that the first question posed to the ICJ in Resolution 71/292 made reference to obligations contained in a number of General Assembly Resolutions, including Resolution 1514(XV) and Resolution 2066(XX), the ICJ observed that the General Assembly had played a central role in the UN's work on decolonisation. ${ }^{100}$ With specific reference to the decolonisation of Mauritius, the General Assembly had acted within the framework of the UN Charter and within the scope of the functions allocated to it to watch over the application of the right to self-determination and to supervise the implementation of the obligations of administering powers. ${ }^{101}$ Those who might be inclined to depict the General Assembly as acting ultra vires on the basis that some of these powers had not originally or explicitly been assigned to it must bear in mind that the UN is not a static organisation but is constantly evolving, and many of its policies have either a basis in the principles and purposes of the UN Charter or have developed as a result of subsequently accepted practice and/or interpretation. ${ }^{102}$ In any case, the member States must be taken to have acquiesced in the General Assembly's assumption of these functions; it is far too late to raise objections seventy years after the fact.

The ICJ proceeded to apply the law to the circumstances of the case and made another pronouncement bound to raise controversy, namely that Mauritius was not in a position to give free consent to the detachment of the Chagos Archipelago. The circumstances surrounding the Lancaster House Agreement called for 'heightened scrutiny'. The ICJ noted that, at the time of the Lancaster House Agreement, Mauritius was still a British colony and consequently 'it is not possible to talk of an international agreement' when one party is under the authority of another. ${ }^{103}$ This appears to be an allusion to the concept of unequal treaties which characterises treaties imposed as a result of unequal bargaining power as null and

\footnotetext{
${ }^{97}$ Chagos case (n 1) [156-157].

${ }^{98}$ Chagos case (n 1) [158].

${ }^{99}$ Described as 'the very sine qua non of all decolonisation', Western Sahara case (n 12) Declaration Judge Nagendra Singh, 81.

${ }^{100}$ Chagos case (n 1) [163]; Cassese describes it as its most successful area, Cassese (n 46) 328-329.

${ }^{101}$ Chagos case (n 1) [167].

${ }^{102}$ Wall case (n 13) [28]; Simon Chesterman, Thomas M Franck and David M Malone, Law and Practice of the United Nations: Documents and Commentary (OUP 2008) 20.

${ }^{103}$ Chagos case (n 1) [172]; see further, Urša Demšar et al, 'The Concept of Duress in the World of Decolonization' (2018) 55 Questions of International Law 119 who argue that the standard of duress in the context of decolonisation is lower than that that would apply between States.
} 


\section{Self-Determination in Light of the International Court of Justice's Opinion in the}

Chagos Case 229

void. ${ }^{104}$ Certainly, this was the view of Judge Kateka and Judge Wolfrum in the Chagos Arbitration who stated that 'there was a clear situation of inequality between the two sides' ${ }^{105}$ They were even more forthright in their condemnation, describing the situation as one of 'duress', 'intimidation' and 'coercion', and considered the UK to have used unacceptable pressure. ${ }^{106}$ These are damning denunciations of the colonial policies of a State that likes to portray itself as law-abiding.

There is also a body of opinion that considers devolution agreements that are coercive, restrictive or contrary to the right of self-determination to be invalid. ${ }^{107}$ While the Chagos Arbitration and the present case brought to light the unpalatable facts of the Premier of Mauritius being subjected to bullying, threats and duress during the Lancaster House process, ${ }^{108}$ no judge raised the possibility of the ensuing Agreement being incompatible with the rule enshrined in Article 51 of the Vienna Convention on the Law of Treaties (VCLT) on coercion of a State's representative. ${ }^{109}$ On the other hand, it could be a reference to the fact that colonies are not subjects of international law, ${ }^{110}$ or at best have limited personality,${ }^{111}$ and accordingly the Lancaster House Agreement could not meet the definition of a treaty as understood by Article 2(1)(a) VCLT. ${ }^{112}$ There is also a third alternative explanation. If colonial self-determination is a jus cogens norm, and there is ample evidence to that effect, ${ }^{113}$ it follows

\footnotetext{
${ }^{104}$ The concept of unequal treaties is denied by Western authorities, Bledsoe and Boczek (n 43) 274-275; Grant and Barker (n 51) 631; Anthony Aust, Handbook of International Law (CUP 2005) 108-109; a variation of the concept was raised unsuccessfully by Libya in Territorial Dispute (Libya/Chad) [1995] ICJ Rep 6; see Gino J Naldi, 'Case Concerning the Territorial Dispute (Libyan Arab Jamahiriya/Chad)' (1995) 44 International and Comparative Law Quarterly 683, 689-690.

${ }^{105}$ Chagos Arbitration (n 2) Dissenting and Concurring Opinion Judge Kateka and Judge Wolfrum 602.

${ }^{106}$ Chagos Arbitration (n 2) Dissenting and Concurring Opinion Judge Kateka and Judge Wolfrum, 602; see further S Allen, The Chagos Islanders and International Law (Hart 2014) Ch 4; it may be unlikely that such political pressure would satisfy the standard for coercion as traditionally understood in the Vienna Convention on the Law of Treaties (adopted 22 May 1969, entered into force 27 January 1980) 1155 UNTS 331 art 52. However, there was a suggestion by the Arbitral Tribunal in Kuwait v American Independent Oil Co (1982) 21 ILM 976 [43], that economic coercion could nullify consent; see further, Demšar (n 102) 128.

${ }^{107}$ See for example ILC, 'Yearbook of the International Law Commission' (1976) vol II, part two, 147; Grant and Barker (n 51) 631; the point has been made that an administering power is under an obligation to act in the best interests of a non-self-governing territory and the Lancaster House Agreement failed to meet this standard, Summers (n 49) 175; see also Chagos Arbitration (n 2) Dissenting and Concurring Opinion Judge Kateka and Judge Wolfrum [75].

${ }^{108}$ See the account in Chagos Arbitration (n 2) Dissenting and Concurring Opinion Judge Kateka and Judge Wolfrum [77].

109 This argument was raised and dismissed by the UK, Written Statement of the United Kingdom (n 8) para 8.17.a.

${ }^{110}$ DW Greig, International Law (2 $2^{\text {nd }}$ ed, Butterworths 1976) 178.

${ }^{111}$ Aust (n 104) 30; Crawford (n 46) 634.

${ }^{112}$ See further, Allen (n 106) 122-123; this proposition may be less defensible in contemporary times as non-selfgoverning territories have assumed a limited capacity to enter into international arrangements, Crawford ( $\mathrm{n} 45)$ 634-635; it is interesting to note that certain colonies could apply for membership of the League of Nations: Covenant of the League of Nations (adopted 28 June 1919, entered into force 1 October 1920) art 1(2) in Malcolm Evans (ed), International Law Documents (9th ed, OUP 2009) 1.

${ }^{113}$ See n 57, n 58, n 59; see also Delimitation of Maritime Boundary between Guinea-Bissau and Senegal (n 45); Arafat and Salah Case (Italian Court of Cassation) (1986-87) 7 Italian Yearbook of International Law 295; 'Commentary on Article 40 ILC Draft Articles on Responsibility of States for Internationally Wrongful Acts (2001)' in DJ
} 
that any treaty incompatible with that norm becomes void in accordance with Articles 53 and/or 64 VCLT. This was the conclusion drawn by a number of the judges. ${ }^{114}$ Whatever the underlying reasons, and regrettably the ICJ did not provide a detailed and reasoned justification for this bold assertion, the ICJ reached the conclusion that the detachment was not based on the free will of the people. ${ }^{115}$

The ICJ stated that the UK, as the administering power, was under an obligation to respect the territorial integrity of Mauritius. Consequently, the detachment of the Chagos Archipelago and the creation of the BIOT meant that the process of the decolonisation of Mauritius was not lawfully completed when Mauritius achieved independence. ${ }^{116}$

\section{State Responsibility}

Having reached the above conclusions, the ICJ turned its attention to the second question: the consequences under international law of the UK's continued administration of the Chagos Archipelago. It concluded that the UK was persisting in a wrongful act of a continuing nature entailing its international responsibility. ${ }^{117}$

The fact that the ICJ described the UK's administration as 'an unlawful act of a continuing character' ${ }^{118}$ is significant in relation to any possible reparation. ${ }^{119}$ However, the only specific remedy the ICJ called for was for a prompt end to the UK's administration of the Chagos Archipelago, leaving it to the General Assembly to decide the modalities for completing the decolonisation of Mauritius. ${ }^{120}$ For Judge Gaja, the ICJ's careful approach was justified by judicial propriety, since to have raised the issue of reparations would have meant intruding on a bilateral dispute. ${ }^{121}$

Harris, Cases and Materials on International Law (7th edn, Sweet \& Maxwell 2010) 452 (ILC Draft Articles on State Responsibility); distinguished scholars supporting this view include Brownlie (n 46) 513; Cassese (n 46) 133-140; John Dugard, International Law: A South African Perspective (Juta 1994) 76; see further, Grant and Barker (n 51) 323.

${ }^{114}$ Chagos case (n 1) Sep Op Judge Sebutinde [28]; Chagos case (n 1) Sep Op Judge Robinson [88], [94]; Chagos case (n 1) Sep Op Judge Cançado-Trindade [124].

${ }^{115}$ Chagos case (n 1) [172]. Judge Sebutinde described the British behaviour as a 'de facto annexation that subverted the right of the people of Mauritius to self-determination by denying them any opportunity to express their will as to the fate of the Chagos Archipelago' Chagos case (n 1) Sep Op Judge Sebutinde [44].

${ }^{116}$ Chagos case (n 1) [173-174].

117 Judge Sebutinde was of the view that the UK had committed a serious breach, Chagos case (n 1) Sep Op Judge Sebutinde [44-46]; whereas Judge Robinson described the UK as being guilty of a 'gross failure', Chagos case ( $\mathrm{n}$ 1) Sep Op Judge Robinson [89].

118 Chagos case (n 1) [177].

${ }^{119}$ Rainbow Warrior (New Zealand v France) (1990) 20 RIAA 217 [264].

${ }^{120}$ Article 30(a) ILC Draft Articles on State Responsibility, in Harris (n 113) 442; Judge Salam raised the possibility of compensation for the Chagossians, Chagos case (n 1) Declaration Judge Salam [7]; Judge CançadoTrindade felt the ICJ should have considered all forms of reparations, Chagos case (n 1) Sep Op Judge CançadoTrindade [257].

${ }^{121}$ Chagos case (n 1) Sep Op Judge Gaja [7]. 


\section{Self-Determination in Light of the International Court of Justice's Opinion in the Chagos Case 231}

Nevertheless, given that respect for the right to self-determination was an obligation erga omnes, ${ }^{122}$ the ICJ pointed out that all States had a legal interest in protecting that right, including co-operating with the General Assembly to that end, as set out in Resolution $2625(\mathrm{XXV}){ }^{123}$ It follows that States are under a duty to not act in a manner that denies that right or impairs its exercise. ${ }^{124}$

The use of the phrase 'obligation erga omnes' rather than 'right erga omnes' ${ }^{125}$ has been welcomed as providing clarification between the two situations in that the former entails a duty owed to the international community, whereas the latter is something of a legal tautology. ${ }^{126}$ The ICJ has used both phrases, as well as 'erga omnes character', ${ }^{127}$ in its jurisprudence without seeming to draw any distinction between them. However, it should be borne in mind that a right erga omnes describes a right '(o)pposable to, valid against, "all the world", ie all other legal persons, irrespective of consent on the part of those thus affected', as opposed to rights that may be bilateral in nature or from which States can contract out. ${ }^{128}$

Unlike after the more egregious violations of international law in the cases of Namibia and Palestine, the ICJ did not call for the non-recognition of the British administration, although this option may be open to the General Assembly if the UK becomes intractable, as seems likely. ${ }^{129}$ If that scenario plays out, the UK could be deemed to be willfully in serious breach of a peremptory norm, as envisaged by Article 40 of the ILC Draft Articles on State Responsibility, amounting to 'aggravated responsibility'. ${ }^{130}$ In such a circumstance, the 'bill' the UK will be compelled to settle will only increase. ${ }^{131}$

Some judges considered that the ICJ should have refrained from making any statement on responsibility. In Judge Tomka's view, the ICJ should have limited itself to holding that the process of decolonisation had yet to be completed in line with the UK's obligations as an administering power. ${ }^{132}$ Judge Gevorgian felt that the issue of responsibility blurred the

\footnotetext{
${ }^{122}$ Barcelona Traction (Belgium v Spain) [1970] ICJ Rep 3 [33]; Wall case (n 13) [155]; see also Council v Front Polisario (n 46) [88].

${ }^{123}$ Chagos case (n 1) [180]; see further, Chagos case (n 1) Sep Op Judge Sebutinde [29]; note Article 41(1) ILC Draft Articles on State Responsibility, in Harris (n 113) 452.

${ }^{124}$ East Timor case (n 46) Diss Op Judge Weeramantry, 204, 221.

${ }^{125}$ East Timor case (n 46) [29]; Wall Case (n 13) [88]; see also, Council v Front Polisario (n 46) [88].

${ }^{126}$ Craig Eggett and Sarah Thin, 'Clarification and Conflation: Obligations Erga Omnes in the Chagos Opinion' (EJIL:TALK!, 21 May 2019) <ejiltalk.org/clarification-and-conflation-obligations-erga-omnes-in-the-chagosopinion/> accessed 25 November 2019.

${ }^{127}$ East Timor Case (n 46) [29]; Wall case (n 13) [156].

${ }^{128}$ Brownlie (n 46) xlix; Grant and Barker (n 51) 188.

${ }^{129}$ Article 41(2) ILC Draft Articles on State Responsibility, in Harris (n 113) 452.

${ }^{130}$ Cassese (n 78) 262.

${ }^{131}$ Article 34 ILC Draft Articles on State Responsibility, in Harris (n 113) 445; in the Commentary on this provision it was stated that in cases involving peremptory norms 'restitution may be required as an aspect of compliance with the primary obligation', Harris (n 113) 446.

${ }^{132}$ Chagos case (n 1) Declaration Judge Tomka [9].
} 
distinction between the ICJ's advisory and contentious jurisdiction. The ICJ's similar determinations in the Namibia case and the Wall case were distinguishable from the present case on the basis that the UN Security Council had previously resolved that the South African and Israeli presence were illegal. ${ }^{133}$ Given the question before it, and once it had decided to respond to it, the minimum the ICJ could do was to give precisely the answer it did.

As against other aspects of the Opinion, the criticism could be made that the ICJ should have elaborated on its reasoning and made clear in greater detail, as it did in the Wall case, the consequences for the violation of international law for all concerned. ${ }^{134}$ Reliance could perhaps have been placed on the ILC Draft Articles on State Responsibility. ${ }^{135}$ However, this may have necessitated the ICJ stating explicitly that self-determination had the status of a peremptory norm of international law, because the concepts of obligations erga omnes and jus cogens are not identical. ${ }^{136}$ This is something the ICJ has abstained from doing, despite urging from some judges, although its description of the right to self-determination as an 'essential' principle of international law is open to the interpretation that it constitutes an implicit acknowledgement of its elevation to that rank. ${ }^{137}$

Concerning the resettlement of the Chagossians, the ICJ decided that this matter should be addressed by the General Assembly as it concerned the protection of human rights. ${ }^{138}$ No doubt, this brief statement will have disappointed those who might have hoped that the ICJ would declare that the Chagossians had a right of return or resettlement. In the Wall case, the ICJ considered the relevance of human rights at some length. ${ }^{139}$ In opting for a pragmatic path, there is no guarantee that at the end of the day any agreement will allow the Chagossians to return, although a resettlement programme seems to be Mauritian government policy. ${ }^{140}$ The General Assembly has since called on both parties to address as a matter of urgency the resettlement of the Chagossians in the decolonisation process and to facilitate their resettlement in the Chagos Archipelago. ${ }^{141}$

\section{Further Developments}

The immediate response of the UK Government to the ICJ's Opinion has been one of defiance. On 30 April 2019, the Foreign Office Minister Alan Duncan stated in Parliament

\footnotetext{
${ }^{133}$ Chagos case (n 1) Declaration Judge Gevorgian [5-6].

${ }^{134}$ Wall case (n 13) [197-200].

${ }^{135}$ A similar criticism was made of the ICJ's Opinion in the Wall case in Susan Breau, 'Legal Consequences of the Construction of a Wall in the Palestinian Territory: Advisory Opinion, 9 July 2004' (2005) 54 International and Comparative Law Quarterly 1003, 1012-1013.

${ }^{136}$ Cassese (n 46) 173; Vera Gowlland-Debbas, 'Judicial Insights into Fundamental Values and Interests of the International Community' in AS Muller and others (eds), The International Court of Justice (Brill 1997) 327, 330.

${ }^{137}$ See Gino J Naldi, 'The East Timor Case and the Role of the International Court of Justice in the Evolution of the Rights of Peoples to Self-Determination' (1999) 5 Australian Journal of Human Rights 106, 118-122.

${ }^{138}$ Chagos case (n 1) [181].

${ }^{139}$ Breau (n 135) 1010-1011.

${ }^{140}$ UNGA, 'General Assembly Welcomes International Court of Justice Opinion on Chagos Archipelago, Adopts Text Calling for Mauritius' Complete Decolonization' (22 May 2019) Press Release GA/12146.

${ }^{141}$ UNGA Res 73/295 (22 May 2019) UN Doc A/Res/73/265 paras 2(f), 4.
} 


\section{Self-Determination in Light of the International Court of Justice's Opinion in the Chagos Case 233}

that, 'We have no doubt about our sovereignty over the Chagos archipelago, which has been under continuous British sovereignty since 1814. Mauritius has never held sovereignty over the archipelago and we do not recognise its claim. ${ }^{142}$ This particular line was reiterated at the UN. ${ }^{143}$ The first problem with this assertion is that it is extremely doubtful that contemporary international law acknowledges an administering power's claims to sovereignty over a nonself-governing territory. ${ }^{144}$ This stance seems to be implicit in Article 73 of the UN Charter and finds further support in Principle V of General Assembly Resolution 2625 (XXV), which states, inter alia, that

'The territory of a colony or other non-self-governing territory has, under the [UN Charter], a status separate and distinct from the territory of the State administering it; and such separate and distinct status under the Charter shall exist until the people of the colony or non-self-governing territory have exercised their right of self-determination'. ${ }^{145}$

Secondly, whether Mauritius itself held sovereignty over the Chagos Archipelago is irrelevant, since Mauritius had never enjoyed independent status prior to 1968. What is material is that, during the colonial era, the Chagos Archipelago was administered as a dependency of Mauritius. ${ }^{146}$ As a result, the principle of uti possidetis was applicable to Mauritius as it achieved independence, so as to preserve its territorial integrity. ${ }^{147}$

Thirdly, British non-recognition of the Mauritian claim is immaterial. The important point is that the Mauritian claim has gained the support of the ICJ and the UN General Assembly and it is the British claim that in fact will henceforth go unrecognised.$^{148}$

The UK Government has also belittled the importance of the case by dismissing it as non-binding. ${ }^{149}$ Technically, this is correct, but this attitude underestimates the legal authority of such judgments as authoritative expositions on points of law and their influence on the conduct of the UN. This observation is so self-evident that it requires no further elucidation. Its immediate impact has been the adoption of Resolution 73/295, wherein the UN General Assembly welcomes the Advisory Opinion, affirms its dispositif, demands that the UK withdraw its colonial administration from the Chagos Archipelago unconditionally within six months, calls upon all member States to cooperate with the UN to secure the speedy decolonisation of Mauritius and to refrain from any action which could hinder this objective and calls upon the UN, its specialised agencies, and other international, regional and intergovernmental organisations to recognise that the Chagos Archipelago forms an integral

\footnotetext{
142 O Bowcott, 'Corbyn condemns May's defiance of Chagos Islands Ruling' (The Guardian, 1 May 2019) $<$ theguardian.com/world/2019/may/01/corbyn-condemns-mays-defiance-of-chagos-islands-ruling > accessed 1 December 2019.

${ }^{143}$ UNGA (n 140).

${ }^{144}$ ILC (n 107) 202; Crawford (n 46) 613-615.

${ }^{145}$ UNGA Res 2625 (XXV) (1970) (n 56).

${ }^{146}$ Chagos case (n 1) [28-29].

${ }^{147}$ Frontier Dispute case (n 45) [23-24].

${ }^{148}$ UNGA Res 73/295 (22 May 2019) UN Doc Res A/RES/73/295 para 6-7; P Sands, 'At Last, the Chagossians

Have a Real Chance of Going Back Home' (The Guardian, 24 May 2019) <theguardian.com/commentisfree/2019/may/24/chagossians-britain-colony-shameful-un-resolution> accessed 1 December 2019.

${ }^{149}$ Bowcott (n 142); UNGA (n 140).
} 
part of Mauritius, to support the prompt decolonisation of Mauritius, and to refrain from recognising or giving effect to any measure taken by the BIOT. ${ }^{150}$

\section{Conclusion}

The Chagos case is important on many levels. It may have been thought that the issue of colonial self-determination was passing into history, except for some stubborn leftovers such as the Falklands and Gibraltar. However, this case reveals that it is still of contemporary relevance.

In a narrow legal sense, the Opinion dealt with several important topics, all of which are contentious to a greater or lesser degree. The ICJ's previous jurisprudence has described the transition of self-determination from a general principle of international law as a broad and ill-defined norm, requiring the prompt demise of colonialism, to a legal right of peoples, establishing principles governing the process of decolonisation.

The Chagos case brings greater clarity and certainty to the law on self-determination, possibly at the expense of provoking further controversy. It found the right to selfdetermination to have crystallised as a rule of customary international law by the mid-1960s at the latest, contrary to the established view of conservative Western States. It upheld the principle of the territorial integrity of non-self-governing territories. It reiterated that respect for the right to self-determination was an obligation erga omnes. It accepted duress as undermining the validity of devolution agreements. At the same time, the ICJ did not always provide fully reasoned arguments to support these bold assertions, leaving itself vulnerable to counterattacks. The Opinion will be hotly debated for some time to come. ${ }^{151}$

The Chagos case has a wider impact on the British body politic. It has proven a diplomatic embarrassment for the UK, exposing publicly and putting under the spotlight shameful episodes of British policy, which has manoeuvred into defending the indefensible. ${ }^{152}$ That the UK should feel the need to defend colonialism in the twenty-first century is discomforting. Wiser counsel and a more astute strategy should have prevailed. However, this is symptomatic of the hubris that is infecting the UK as it contemplates a post-brexit future. British MPs may indulge in delusional fantasies about resurrecting the Empire, but they overlook the fact their jingoism is toxic to much of the international community. They refuse to acknowledge the reality that such tomfoolery is accelerating or causing a decline in the UK's international standing and influence. ${ }^{153}$ Colonialism belongs in the history books.

The Chagos case has broader implications for active colonial disputes. In particular, it raises questions about France's hold over Mayotte, and Cyprus has already indicated that it

\footnotetext{
${ }^{150}$ UNGA Res 73/295 (n 148).

${ }^{151}$ For a positive review of the case see Diane M Amann, 'Legal Consequences of the Separation of the Chagos Archipelago from Mauritius in 1965' (2019) 113 American Journal of International Law 784.

152 'The Guardian view on Britain and the Chagos Islands: A Wake-up Call from the World' (The Guardian, 23 May 2019) <theguardian.com/commentisfree/2019/may/23/the-guardian-view-on-britain-and-the-chagosislands-a-wake-up-call-from-the-world> accessed 1 December 2019.

${ }^{153}$ House of Commons Foreign Affairs Committee, '2017 Elections to the International Court of Justice' (HC 2017-2019, 860); Nahal Toosi, 'Little Britain? The UK Loses its Mojo in Washington: Close Observers Say Britain's influence in Washington is at a Low Point' (Politico, 31 May 2019) < politico.eu/article/little-britainthe-uk-loses-its-mojo-in-washington-donald-trump-theresa-may-brexit-special-relationship/> accessed 1 December 2019.
} 


\section{Self-Determination in Light of the International Court of Justice's Opinion in the \\ Chagos Case 235}

strengthens its hand as it seeks to renegotiate the status of the British bases there. ${ }^{154}$ It underlines the necessity of finding an acceptable solution to the on-going neo-colonial occupation of the Western Sahara.

The General Assembly has set a six-month deadline for the UK to withdraw unconditionally from the Chagos Archipelago. That deadline has now passed and it is not yet clear what the next steps may be. ${ }^{155}$ Robust action by the UN Security Council can be discounted in light of the UK veto. The Prime Minister of Mauritius has publicly stated his willingness to enter into a long-term understanding with the UK and the USA over the Archipelago.${ }^{156}$ Various possibilities could be canvassed which need not disturb the status quo, including the possibility of a lease, such as Kowloon or the Panama Canal Zone, ${ }^{157}$ a condominium, such as the New Hebrides, ${ }^{158}$ or an outright purchase. ${ }^{159}$ All of these options would be legally acceptable if freely negotiated and accepted by Mauritius, the lawful sovereign.

The UK is holding a weak hand; bluster and defiance of the ICJ and the UN will serve little purpose. Acknowledging reality with grace and negotiating a sensible solution is the way forward.

www.grojil.org

\footnotetext{
${ }^{154}$ Constantinos Yiallourides, 'Cyprus Gains Legal Tool in ICJ Ruling on Chagos Islands' (Law 360, 15 March 2019) <papers.ssrn.com/sol3/papers.cfm?abstract_id=3351969> accessed 1 December 2019.

155 BBC News, 'Chagos Islands dispute: UK misses deadline to return control' (22 November 2019) $<$ https://www.bbc.co.uk/news/uk-50511847> accessed 2 January 2020.

${ }^{156}$ Michelle Nichols 'U.N. deals diplomatic blow to Britain and U.S. over Indian Ocean islands' (Reuters, 22 May 2019)

$<$ https://www.reuters.com/article/us-britain-mauritius-un/u-n-deals-diplomatic-blow-to-britain-and-u-s-overindian-ocean-islands-idUSKCN1SS2CR> accessed 2 January 2020.

${ }^{157}$ Aust (n 104) 39.

${ }_{158}$ Aust (n 104) 31.

${ }^{159}$ Bledsoe and Boczek (n 43) 144-145.
} 